\title{
Would Aluminum and Nickel Content of Apricot Pose Health Risk to Human?
}

\author{
Gholamhossein DAVARYNEJAD ${ }^{*}$, Safieh VATANDOOST ${ }^{1}$, Hamed KAVEH $^{1}$, Tamas Peter NAGY² \\ ${ }^{1}$ Ferdowsi University of Mashhad, Department of Horticultural Science, PO Box 91775-1163, Iran; davarynej@um.ac.ir (*corresponding author) \\ ${ }^{2}$ University of Debrecen, Institute for Research and Development, 138 Böszörményi Street, H-4032 Debrecen, Hungary
}

\begin{abstract}
Higher demands of food production for human consumption increased uses of fertilizers and other chemicals that arise in a major public problem and heavy-metal pollution. Levels of Aluminum and Nickel which affect mankind health in exact doses, were determined in fresh and dried samples of 'Jumbo Cot,' 'Tom Cot,' 'Gold Strike,, 'Gold Bar,' Bergeron,' 'Bergarouge,' 'Sweet Cot,' 'Yellow cot' and 'Zebra' apricot cultivars to assess possible health risk of apricot (Prunus armeniaca L.) consumption. Highest content of $\mathrm{Al}$ and $\mathrm{Ni}$ among all cultivars, where 9.71 and $2.14 \mathrm{mg} / \mathrm{kg}$ of dehydrated apricot samples. Fresh fruit samples maximally contain 2.9 and $0.425 \mathrm{mg} / \mathrm{kg}$ of Aluminum and Nickel respectively. Data analysis showed significant differences between cultivars for $\mathrm{Al}$ and Ni. Furthermore, to reveal the health-risk possibility of dried and fresh fruit consumption daily intake of elements and health-risk index were calculated and compared.
\end{abstract}

Keywords: chemical composition, heavy metals, health risk index; Prunus armeniaca L.

\section{Introduction}

The metal contents of food are gaining importance because of toxicological as well as their nutritional viewpoints. Dietary intake is considered to be the major supplier of these elements for the body (Demirozu et al., 2002). Heavy metals normally occurring in nature are not harmful, because they are only present in very small amounts. However, if the levels of these metals are elevated, then they can show negative effects (Tuzen, 2007). Aluminum is a non-essential metal that would be toxic even in trace amounts (Gogoasa et al., 2005). Human exposure to heavy metals can occur through a variety of routes, such as inhalation of air pollutants or contaminated soil particles and consumption of contaminated foods (Bordajandi et al., 2004). Heavy metals contamination of orange fruits by Rossini et al. (2003), plantain by Selema and Farago (1996), mango and almond by Ademoroti (1986), lemon, sweet orange and grapefruits by Gorinstein et al. (2001), chiku, papaya, mango, muskmelon and apple by Parveen et al. (2003), quince and grape by Pinochet et al. (1999), strawberry by Ward and Savage (1994), banana, pineapple and papaya by Santos et al. (2004) mango and almond fruits by Ademoroti ( 1986) and Li et al. (2006), date palm by Williams et al. (2005) and apricot by Saracoglu et al. (2009) were studied.

Apricots like other fruits constitute a rich source of vitamins and minerals (Munzuroglu et al., 2003), and they are rich in $\beta$-carotenes. About $15-20 \%$ of apricots produced are consumed fresh and the rest are processed as canned, dried, frozen, jam, juice, and puree (Hui, 2006). Dried apricots are a concentrated source of fiber and one of the highly nutrient-dense dried fruits (Rieger, 2004).

The purpose of the present study is determining the concentration of $\mathrm{Al}$ and $\mathrm{Ni}$ in 9 apricot cultivars grown in Hungry and to estimate their contribution to the human daily intake of those elements by using daily intake of metals (DIM) and health risk index (HRI) to reveal health risk possibility of dried and fresh fruits consumption $(\mathrm{Li}$, 2009).

\section{Materials and methods}

\section{Plant material}

Nine medium and late-ripening apricot cultivars, 'Jumbo Cot,' 'Tom Cot', Goldstrike, Goldbar, 'Bergeron', 'Bergarouge', 'Sweet Cot', 'Yellow Cot' and 'Zebra' harvested by physiological maturity stage from Boldogkőváralja commercial orchard of Debrecen (Hungary).

\section{Analysis method}

Homogenized fresh and dried fruit's samples in three replicates were used for chemical analysis. Sample preparing to be in accordance with Hungarian standard (MSZ-08-1783-15:1985) For hot air drying a household tray-dryer (Model Hauser) was used. The stoned and nonsulfurated fruits were hot air dried for 24 hours to get dehydrated samples. Seeded; milled fruits without peeling were digested with concentrate $\mathrm{HNO}_{3}-\mathrm{H}_{2} \mathrm{O}_{2}$ digester mixture. Five grams fresh fruit ( $2 \mathrm{~g}$ dehydrated fruit) was 
92

digested at $120^{\circ} \mathrm{C}$ during three hours in a Teflon digester. Digested samples diluted with distilled water to $100 \mathrm{~cm}^{3}$. Examined elements were measured by Thermo Jarrell Ash Poly-scan 61E and Thermo Electron Corporation IRIS Intrepid II XDL Inductively coupled plasma emission spectrophotometers (ICP).

\section{The investigated parameters}

\section{Daily Intake of Metals (DIM)}

To evaluate this factor, the following equation was used.

$\mathrm{DIM}=\mathrm{C}_{\text {mexal }} \times \mathrm{C}_{\text {fictor }} \times \mathrm{D}_{\text {food inate }} / \mathrm{B}_{\text {average we wight }}$

Where, $\mathrm{C}_{\text {metal }}$ is heavy metals conc. in plants $(\mathrm{mg} / \mathrm{kg}$ ), $\mathrm{C}_{\text {factor }}$ is conversion factor to change fresh weight to dry weight, $\mathrm{D}_{\text {food intake }}$ is daily intake of fruit, $\mathrm{B}_{\text {average weight }}$ is body weight.

\section{Health Risk Index (HRI)}

By using Daily Intake of Metals (DIM) and reference oral dose the health-risk index were obtained.

HRI =DIM / RfD.

If the value of HRI is less than 1 then the exposed population is said to be safe (Khan, 2009).

\section{Results and discussion}

\section{Aluminium}

Although aluminium is the most widespread metal on the Earth's surface ( $8 \%$ of Earth's crust), nearly all foods contain small amounts of aluminum. Aluminum absorption of human beings is difficult to estimate. The degree of absorption has been estimated to be at least $0.2 \%$ (Elinder et al., 1994). The daily average intake estimated vary from 2 to 10 mg.day ${ }^{-1}$ (Biego, 1998; Greger, 1985; Pennington, 1987). Some vegetable preparations (tea leaves, coffee beans, spices and herbs) and fruits contain more aluminum than foods of animal origin (Biego,1998). The possible connection between elevated tissue $\mathrm{Al}$ content and problems such as osteomalacia and neurodegenerative disorders has awakened interest in Al's intake via the diet (Lopez et al., 2006). Data analysis showed significant differences between apricot cultivars for both fresh and dry samples (Fig. 1).

HRI and DIM calculated for Al's content of examined Hungarian apricot cultivars (Tab. 1), show that using 100 gr of dried apricots daily for a $60 \mathrm{~kg}$ human may not pose the exposed population by any problems, which made by Aluminium toxicity. HRI for all cultivars was less than 1, which means that they may be safe for exposed population

\section{Nickel}

Nickel ingestion in humans occurs through the consumption of plant and animal products. Vegetables such as legumes, spinach, lettuce, and nuts contain more nickel than other foods. In plants such as potatoes and corn, metals including nickel are primarily ligated to polysaccharides such as amylose and amylopectins (Ciesielski and Tomasik, 2004). The biological half-time or nickel clearance is on the order of 2-3 days (Onkelinx et al., 1973). Acute nickel poisoning by inhalation exposure or ingestion of nickel carbonyl or soluble nickel compounds can lead to headache, vertigo, nausea, vomiting, nephrotoxic effects, and pneumonia followed by pulmonary fibrosis. Chronic effects of nickel exposure by inhalation are reported among nickel refinery and plating workers to include rhinitis, sinusitis, nasal septum perforations, and asthma. Nickel is also hepatotoxic, and studies show that zinc can prevent nickel-induced toxicity and maintain normal levels and function of liver enzymes (Sidhu et al., 2004). Nickel, like other metals, can induce systemic lipid peroxidation and can deplete glutathione, most likely through oxidative stress mechanisms (Kasprzak et al., 2003; Valko et al., 2005). Nickel concentration of apricot samples in the

Tab. 1. Health Risk Index (HRI) and Daily Intake of Metals (DIM) calculated for Al's content of examined Hungarian apricot cultivars

\begin{tabular}{cccc}
\hline Cultivar & $\begin{array}{c}\text { Element content } \\
\mathrm{mg} . \mathrm{kg}^{-1}\end{array}$ & DIM & HRI \\
\hline 'Zebra' & 5.40653 & 0.009010883 & 0.128726905 \\
\hline 'Sweet Cot' & 5.484946667 & 0.009141578 & 0.130593968 \\
\hline 'Gold Bar' & 6.274963333 & 0.010458272 & 0.149403889 \\
\hline 'Jumbo Cot' & 6.794073333 & 0.011323456 & 0.161763651 \\
\hline 'Tom Cot' & 7.212873333 & 0.012021456 & 0.171735079 \\
\hline 'Bergeron' & 7.871773333 & 0.013119622 & 0.187423175 \\
'Yellow Cot' & 9.025483333 & 0.015042472 & 0.21489246 \\
\hline 'Gold Strike' & 9.184503333 & 0.015307506 & 0.218678651 \\
\hline 'Bergarouge' & 9.72733 & 0.016212217 & 0.231603095 \\
\hline
\end{tabular}

DIM was calculated for consumption of $100 \mathrm{~g}$ of dry apricots. Body weight used was $60 \mathrm{~kg}$. RfD doses was adapted from ATSDR, 2008

Tab. 2. Health Risk Index (HRI) and Daily Intake of Metals (DIM) calculated for Ni's content of examined Hungarian apricot cultivars

\begin{tabular}{cccc}
\hline Cultivar & $\begin{array}{c}\text { Element } \\
\text { content mg.kg-1 }\end{array}$ & DIM & HRI \\
\hline 'Yellow Cot' & 0.313046667 & 0.000521744 & 0.026087222 \\
\hline 'Gold Bar' & 0.80923 & 0.001348717 & 0.067435833 \\
\hline 'Bergarouge' & 0.83065 & 0.001384417 & 0.069220833 \\
\hline 'Sweet Cot' & 1.258183333 & 0.002096972 & 0.104848611 \\
\hline 'Jumbo Cot' & 1.62685 & 0.002711417 & 0.135570833 \\
'Gold Strike' & 1.742893333 & 0.002904822 & 0.145241111 \\
\hline 'Bergeron' & 1.78471 & 0.002974517 & 0.148725833 \\
\hline 'Tom Cot' & 2.09001 & 0.00348335 & 0.1741675 \\
\hline 'Zebra' & 2.143413333 & 0.003572356 & 0.178617778 \\
\hline
\end{tabular}

DIM was calculated for consumption of $100 \mathrm{~g}$ of dry apricots. Body weight used was $60 \mathrm{~kg}$. RfD doses was adapted from ATSDR, $2005(0.02 \mathrm{mg} / \mathrm{kg} /$ day $)$ 


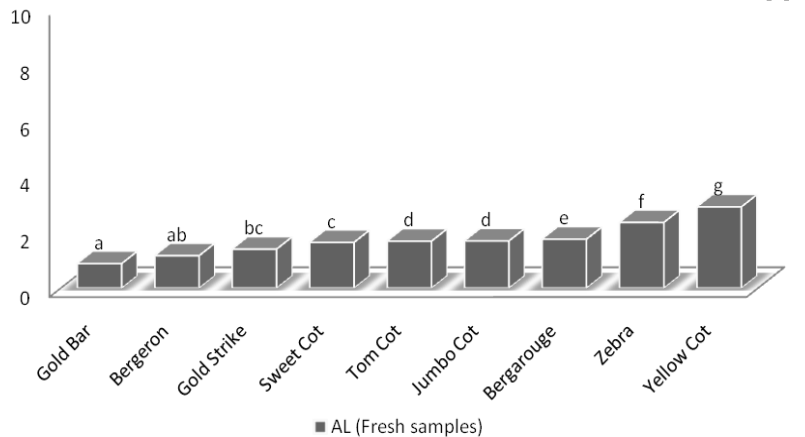

B

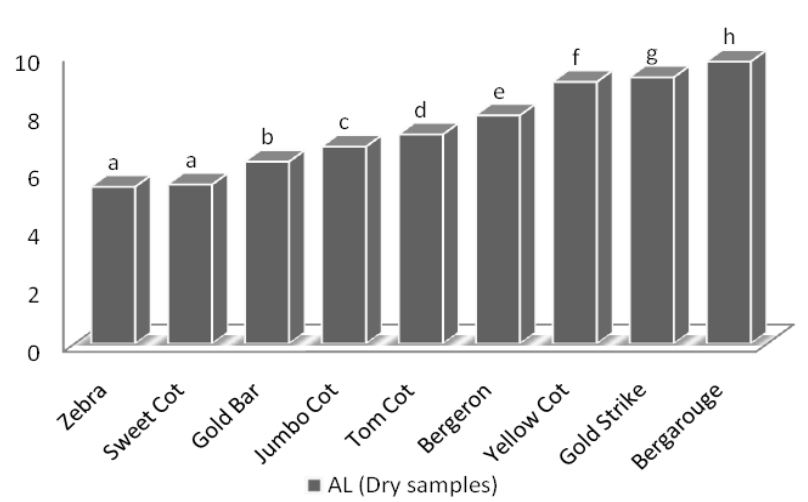

Fig. 1. Concentration of Aluminium in apricot cultivars. A: Fresh and B: Dry samples. Columns with different caption have a significant difference $(p \leq 1 \%)$

present study range between $0.116-2.15 \mathrm{mg} / \mathrm{kg}$ (Fig. 2). Nickel contents in the literature have been reported in the range $1.0-8.9 \mathrm{mg} / \mathrm{kg}$ in summer fruits from Pakistan ( $\mathrm{Za}$ hoor et al., 2003) and in the range of 2.30-5.83 in apricots from Turkey (Saracoglu, 2009) and $1.119 \mathrm{mg} / \mathrm{kg}$ in apricots in Pakistan's market (Zahir et al., 2009). For Nickel, 'Yellow Cot' had the lowest and 'Zebra' had the highest concentration, 0.31 and $2.14 \mathrm{mg} . \mathrm{kg}^{-1}$ respectively.

HRI and DIM calculated for Ni content of examined Hungarian apricot cultivars (Tab. 2) show that using 100 gr of dried apricots daily for a $60 \mathrm{~kg}$ human may not pose the exposed population by any problems, which made by Nickel toxicity. HRI for all cultivars was less than 1, which means that they may be safe for exposed population

In the same study on these cultivars for $\mathrm{Hg}, \mathrm{As}, \mathrm{Pb}$, and $\mathrm{Cd}$, calculated HRI and DIM show that using $100 \mathrm{gr}$ of dried apricots daily for a $60 \mathrm{~kg}$ human may pose the exposed population by some problems, which made by $\mathrm{Hg}$ and As toxicity (Davarynejad et al., 2010).

\section{Conclusions}

In regular diet, fruits have been strongly associated with reduced risk of some forms of cancer, heart disease, stroke and other chronic ailments. In conclusion, this study shows that hazardous element content of 9 examined apricot cultivars were less than the world limit and daily intake of fresh or dried apricots may not cause serious problems.
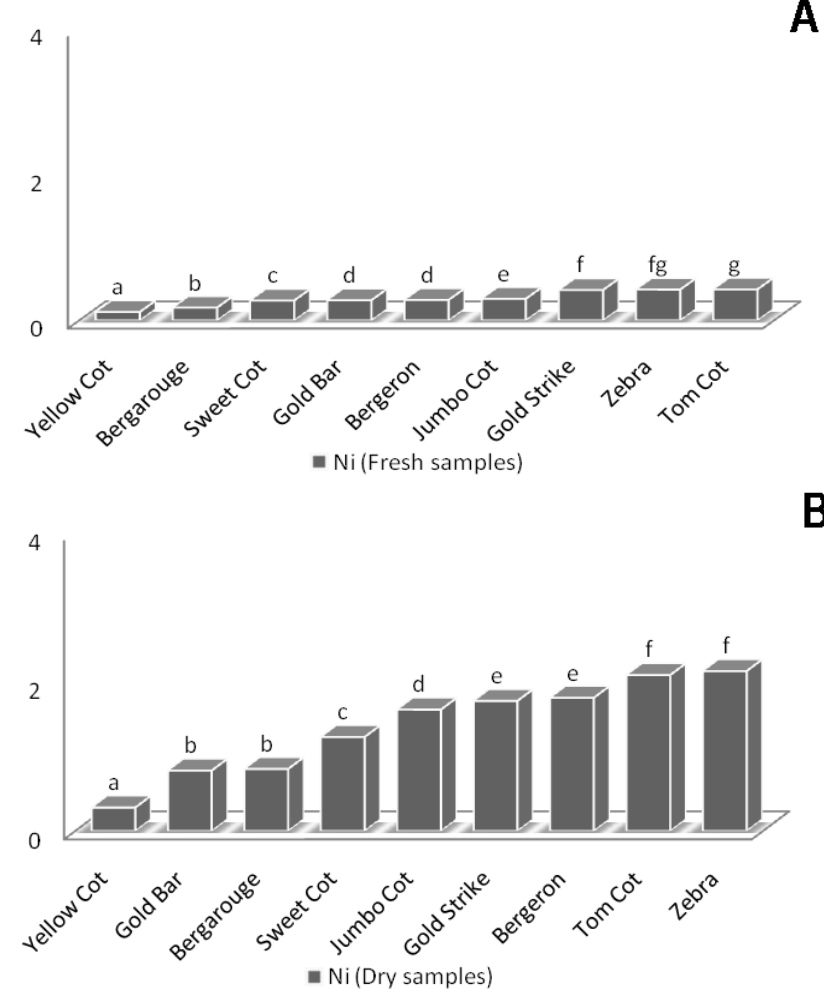

Fig. 2. Concentration of Nickel in apricot cultivars. A: Fresh and B: Dry samples. Columns with different caption have a significant difference $(p \leq 1 \%)$

\section{References}

Ademoroti MCA (1986). Levels of heavy metals on bark and fruit trees in Benin City, Nigeria. Environ Poll Ser B 11:241253.

Arora M, Kiran B, Rani Sh, Rani A (2008). Heavy metal accumulation in vegetables irrigated with water from different sources. Food Chem 111(4):811-815.

Biego GH (1998). Daily intake of essential minerals and metallic micro pollutants from foods in France. The Sci Total Environt 217:27-36.

Bordajandi LR, Gomez G, Abad E, Rivera J, del Mar FernandezBaston M, Blasco J, Gonzalez MJ (2004). Survey of persistent organochlorine contaminants (PCBs, PCDD/Fs, and PAHs), heavy metals ( $\mathrm{Cu}, \mathrm{Cd}, \mathrm{Zn}, \mathrm{Pb}$, and $\mathrm{Hg}$ ), and arsenic in food samples from Huelva Spain: levels and health implications. J Agric Food Chem 52:992-1001.

Ciesielski W, Tomasik P (2004). Complexes of amylose and amylopectins with multivalent metal salts. J Inorg Biochem 98(12):2039-2051.

Davarynejad GH, Vatandoost S, Soltész M, Nyéki J, Szabó Z, Nagy PT (2010). Hazardous element content and consumption risk of nine apricot cultivars. Internat J Hortic Sci 16(4):61-65.

Demirozu B, Sokmen M, Ucak A, Yılmaz H, Gulderen S (2002). Variation of copper, iron and zinc levels in pekmez products. Bull Environ Contam Toxicol 69:330-334. 
94

Eckel H, Roth U, Döhler H, Nicholson F, Unwin R (2005). Assessment and reduction of heavy metal trace metal input into agro-ecosystems. Final report of EU-concerted action. AROMIS. KTBL-Schrift 432. Darmstadt, Germany.

Elinder CG, Friberg L, Kjellstrom T, Nordberg G, Oberdoerster G (1994). Biological monitoring of metals. WHO/ EHG/94.2.Geneva, 78 p.

Gogoasa I, Marutoiu C, Gergen I, Rada M, Tigae C (2005). The use of vegetables as indicators in determining the environment pollution. Revista De Chimie 56:1275-1276.

Gorinstein S, Martın-Bellosob O, Parkc YS, Haruenkitd R, Milanciz AL, Caspi A, Libmanf I, Trakhtenbergf S (2001). Comparison of some biochemical characteristics of different citrus fruits. Food Chem 74:309-315.

Gratani L, Varonea L (2008). Long-term monitoring of metal pollution by urban trees. Atmospheric Environ 42(35):82738277.

Greger JL (1985). Aluminium content of American diet. Food Technol 39:73-80.

Hui YH (2006). Handbook of fruits and fruit processing. $1^{\text {st }} \mathrm{ed}$. Blackwell Publishing. Oxford, 279-291 p.

Kasprzak KS, Sunderman FW Jr, Salnikow K (2003). Nickel carcinogenesis. Mutat Res 533(1-2):67-97.

Khan S, Farooq R (2009). Health risk assessment of heavy metals for population via consumption of vegetables. World Appl Sci J 6(12):1602-1606.

Li JT, Qiu JW, Wang XW, Zhong Y, Lan CY, Shu WS (2006). Cadmium contamination in orchard soils and fruits tree and its potential health risk in Guangzhou, China. Environ Poll 143:159-165.

Li P, Wang X (2009). Risk assessment of heavy metals in soil previously irrigated with industrial wastewater in Shenyang, China. J Hazardous Mater 161:516-521.

Lopez FF, Cabrera C, Lorenzo ML, Lopez MC (2006). Aluminium content of drinking waters, fruit juices and soft drinks: contribution to dietary intake. The Sci Total Environ 292:205-213.

Lugon-Moulin N, Ryan L, Donini P, Rossi L. Cadmium content of phosphate fertilizers used for tobacco production (2006). Agron Sustain Develop 26:151-5.

Munzuroglu O, Karatas F, Geckil H (2003). The vitamin and selenium contents of apricot fruit of different varieties cultivated in different geographical regions, Food Chem 83:205-212.

Onkelinx C,BeckerJ,Sunderman FWJr.(1973). Compartmental analysis of the metabolism of $63 \mathrm{Ni}$ (II) in rats and rabbits. Res Comm Chem Pathol Pharmacol 6(2):663-76.
Parveen Z, Khunhro MI, Rafig N (2003). Market basket survey for lead, cadmium, copper, chromium, nickel and zinc fruits and vegetables. Bull Environ Contamin Toxicol 71:12601264.

Pennington JAT (1987). Aluminium content of foods and diets. Food Add Contam 5:161-232.

Pinochet H, De Gregori I, Lobos MG, Fuentes E (1999). Selenium and copper in vegetables and fruits grown on long term impacted soils from Valparaiso Region, Chile. Bull Environ Contamin Toxicol 63:327-334.

Rieger M (2004). Mark's Fruit Crops Homepage, University of Georgia, http://www.uga.edu/fruit.

Santos EE, Lauria DC, Porto da Silveiro CL (2004). Assessment of daily of trace elements due to consumption of foodstuffs by adult inhabitants of Rio de Janeiro city. Sci Total Environ 327:69-79.

Saracoglu S, Tuzenb M, Soylakc M (2009). Evaluation of trace element contents of dried apricot samples from Turkey. J Hazardous Mater 167:647-652.

Selema MD, Farago ME (1996). Tarce element concentrations in the fruit peels and trunks of Musa paradisiaca. Phytochem 42(6):1523-1525.

Sidhu P, Garg ML, Dhawan DK (2004). Protective role of zinc in nickel induced hepatotoxicity in rats. Chem Biol Interact 150(2):199-209.

Tuzen M (2007). Evaluation of trace element contents in canned foods marketed from Turkey. Food Chem 102:1089-1095.

Valko M, Morris H, Cronin MTD (2005). Metals, toxicity and oxidative stress. Curr Med Chem 12(10):1161-1208.

WangX,Sato T,Xing B, TaoS (2005). Health risks of heavy metals to the general public in Tianjin, China via consumption of vegetables and fish. Sci Total Environ 350:28-37.

Ward NI, Savage JM (1994). Metal dispersion and transportational activities using food crops as biomonitors. Sci Total Environ 146/147:309-319.

Williams JR, Pillaya AE, El Mardi MO (2005). Levels of selected metals in the Fard cultivar (date palm). J Arid Environ 60:211-225

Zahir E, Naqvi II, Uddin SM (2009). Market basket survey of selected metals in fruits from Karachi city (Pakistan). J Basic Appl Sci 5(2):47-52.

Zahoor A, Jaffar M, Saqib M (2003). Elemental distribution in summer fruits of Pakistan. Nutr Food Sci 33(5):203-207. 